\title{
Hypoxia-induced endocytosis of $\mathrm{Na}, \mathrm{K}$-ATPase in alveolar epithelial cells is mediated by mitochondrial reactive oxygen species and PKC- $\zeta$
}

\author{
Laura A. Dada, ${ }^{1}$ Navdeep S. Chandel, ${ }^{1}$ Karen M. Ridge, ${ }^{1}$ Carlos Pedemonte, ${ }^{2}$ \\ Alejandro M. Bertorello, ${ }^{3}$ and Jacob I. Sznajder ${ }^{1}$ \\ ${ }^{1}$ Division of Pulmonary and Critical Care Medicine, Northwestern University, Chicago, Illinois, USA \\ ${ }^{2}$ Department of Pharmacological and Pharmaceutical Sciences, College of Pharmacy, University of Houston, \\ Houston, Texas, USA \\ ${ }^{3}$ Department of Medicine, Atherosclerosis Research Unit, Karolinska Institutet, Karolinska Hospital, Stockholm, Sweden
}

\begin{abstract}
During ascent to high altitude and pulmonary edema, the alveolar epithelial cells (AEC) are exposed to hypoxic conditions. Hypoxia inhibits alveolar fluid reabsorption and decreases $\mathrm{Na}, \mathrm{K}$-ATPase activity in AEC. We report here that exposure of AEC to hypoxia induced a time-dependent decrease of $\mathrm{Na}, \mathrm{K}-\mathrm{ATPase}$ activity and a parallel decrease in the number of $\mathrm{Na}, \mathrm{K}-\mathrm{ATPase} \alpha_{1}$ subunits at the basolateral membrane (BLM), without changing its total cell protein abundance. These effects were reversible upon reoxygenation and specific, because the plasma membrane protein GLUT1 did not decrease in response to hypoxia. Hypoxia caused an increase in mitochondrial reactive oxygen species (ROS) levels that was inhibited by antioxidants. Antioxidants prevented the hypoxia-mediated decrease in $\mathrm{Na}, \mathrm{K}$-ATPase activity and protein abundance at the BLM. Hypoxia-treated AEC deficient in mitochondrial DNA ( $\rho^{0}$ cells) did not have increased levels of ROS, nor was the Na,K-ATPase activity inhibited. Na,K-ATPase $\alpha_{1}$ subunit was phosphorylated by PKC in hypoxia-treated AEC. In AEC treated with a PKC- $\zeta$ antagonist peptide or with the $\mathrm{Na}, \mathrm{K}-\mathrm{ATPase} \alpha_{1}$ subunit lacking the PKC phosphorylation site (Ser-18), hypoxia failed to decrease $\mathrm{Na}, \mathrm{K}-\mathrm{ATPase}$ abundance and function. Accordingly, we provide evidence that hypoxia decreases $\mathrm{Na}, \mathrm{K}$-ATPase activity in AEC by triggering its endocytosis through mitochondrial ROS and PKC- $\zeta$-mediated phosphorylation of the Na,K-ATPase $\alpha_{1}$ subunit.
\end{abstract}

J. Clin. Invest. 111:1057-1064 (2003). doi:10.1172/JCI200316826.

\section{Introduction}

Pulmonary edema is cleared predominantly through active $\mathrm{Na}^{+}$transport from the airspaces (1-3). The active $\mathrm{Na}^{+}$transport generates a transepithelial osmotic gradient that leads to alveolar fluid reabsorption. Sodium enters the apical membrane of alveolar epithelial cells (AEC) through amiloride-sensitive $\mathrm{Na}^{+}$channels (4-6) and is then transported out across the basolateral membrane (BLM) by the ouabain-inhibitable Na,K-ATPase $(7,8)$. The Na,K-ATPase is a heterodimer composed of an $\alpha$ and a $\beta$ subunit. The $\alpha$ subunit is a transmem-

Received for publication September 4, 2002, and accepted in revised form January 28, 2003.

Address correspondence to: Jacob I. Sznajder, Division of Pulmonary and Critical Care Medicine, Northwestern University, 303 East Chicago Avenue, Tarry Building 14-707, Chicago, Illinois 60611, USA. Phone: (312) 908-7737; Fax: (312) 908-4650; E-mail: j-sznajder@northwestern.edu.

Conflict of interest: The authors have declared that no conflict of interest exists.

Nonstandard abbreviations used: alveolar epithelial cells (AEC); basolateral membrane (BLM); reactive oxygen species (ROS); catalase-polyethylene glycol (PEG-catalase); N-acetyl-L-cysteine (NAC); thenoyltrifluoroacetone (TTFA); t-butyl hydroperoxide $\left(\mathrm{t}-\mathrm{H}_{2} \mathrm{O}_{2}\right.$ ); 1,2-dioleoyl-sn-glycerol (DAG); L- $\alpha$-phosphatidyl-Lserine (PS); 1,4-diazabicyclo-[2.2.2] octane (DABCO); bisindolylmaleimide I (Bis); $2^{\prime}, 7^{\prime}$-dichlorofluorescein diacetate (DCFH-DA); $2^{\prime}, 7^{\prime}$-dichlorofluorescein (DCF); hypoxia-inducible factor- $1 \alpha(\mathrm{HIF}-1 \alpha)$; antimycin A (AA). brane protein that cleaves high-energy phosphate bonds and exchanges intracellular $\mathrm{Na}^{+}$for extracellular $\mathrm{K}^{+}(9)$. The smaller $\beta$ subunit is a glycosylated transmembrane molecule that controls the heterodimer assembly and insertion into the plasma membrane (10).

At sea level, the fraction of inspired oxygen is 0.21 , and the alveolar $\mathrm{O}_{2}$ partial pressure is approximately 150 torr. The highest $\mathrm{pO}_{2}$ detected in the body is at the surface of the alveolar epithelium, which is approximately 100 torr $\left(16 \% \mathrm{O}_{2}\right)$. In contrast, most other tissues in the body have a $\mathrm{pO}_{2}$ around approximately 40 torr or $6 \%$. However, during many pathophysiological conditions, severe alveolar hypoxia may develop. For example, during the ascent to high altitude, a decrease in alveolar oxygen tension $\left(1.5-4 \% \mathrm{O}_{2}\right)$ can occur as the consequence of decreased barometric pressure. Also, alveolar hypoxia may be a consequence of pulmonary edema associated with acute lung injury or congestive heart failure. Previous reports have demonstrated that hypoxia in vivo decreases vectorial $\mathrm{Na}^{+}$transport and thus alveolar fluid clearance $(11,12)$. In vitro, hypoxia inhibits active $\mathrm{Na}^{+}$ transport by impairing the activity of both $\mathrm{Na}^{+}$channels and $\mathrm{Na}, \mathrm{K}$-ATPase, whereas a more prolonged exposure downregulates their gene expression $(11,13-15)$.

Recent studies have implicated the mitochondria in the $\mathrm{O}_{2}$-sensing mechanism underlying the functional responses to hypoxia (16). Although superoxide anions 
$\left(\mathrm{O}_{2}^{-}\right)$and $\mathrm{H}_{2} \mathrm{O}_{2}$ are generally considered to be toxic byproducts of cellular respiration, recent evidence suggests that the production of these reactive oxygen species (ROS) may participate in signal transduction pathways $(17,18)$. It has been suggested that hypoxia partially inhibits mitochondrial electron transport, resulting in redox changes in the electron carriers that increase the generation of ROS (19). These oxidants then enter the cytosol and can function as second messengers.

The Na,K-ATPase activity can be regulated by changes in catalytic activity brought about by changes in affinity for its major substrates. However, recent reports have demonstrated that the $\mathrm{Na}$,K-ATPase activity is regulated through the endocytosis or exocytosis of $\mathrm{Na}^{+}$pump molecules between the plasma membrane and intracellular compartments (20-23). Here, we have conducted experiments to elucidate the pathway by which severe hypoxia decreases $\mathrm{Na}, \mathrm{K}$-ATPase activity in alveolar epithelial cells. The results provide evidence that short-term hypoxia decreases $\mathrm{Na}$,K-ATPase activity through the endocytosis of the Na,K-ATPase molecules from the plasma membrane to intracellular compartments, which is reversible upon reoxygenation and mediated by the mitochondria-generated ROS, the activation of PKC- $\zeta$, and the phosphorylation of Ser-18 of the $\mathrm{Na}$,K-ATPase $\alpha_{1}$ subunit.

\section{Methods}

Materials. Na,K-ATPase $\alpha_{1}$ subunit monoclonal antibody (clone 464.6) was purchased from Upstate Biotechnology (Lake Placid, New York, USA). GLUT1 antibody was purchased from Chemicon (Temecula, California, USA), ouabain from ICN Biomedicals Inc. (Aurora, Ohio, USA), and ebselen from Alexis Biochemicals (San Diego, California, USA). Leupeptin, catalase-polyethylene glycol (PEG-catalase), antimycin A, rotenone, $\mathrm{N}$-acetyl-L-cysteine (NAC), thenoyltrifluoroacetone (TTFA), t-butyl hydroperoxide $\left(\mathrm{t}-\mathrm{H}_{2} \mathrm{O}_{2}\right)$, 1,2-dioleoyl-sn-glycerol (DAG), $\mathrm{L}$ - $\alpha$-phosphatidyl-L-serine (PS), and 1,4-diazabicyclo[2.2.2] octane (DABCO) were purchased from SigmaAldrich (St Louis, Missouri, USA). Bisindolylmaleimide I (Bis) and rat brain PKC were purchased from Calbiochem (San Diego, California, USA). Percoll was purchased from Amersham Pharmacia Biotech (Uppsala, Sweden), GFP polyclonal antibody was purchased from Clontech (Palo Alto, California, USA), and A/G PLUS-Agarose was obtained from Santa Cruz Biotech (Santa Cruz, California, USA). All other reagents were commercial products of the highest grade available. Daria Mochly-Rosen kindly provided the following PKC isozyme-specific peptide antagonists: PKC- $\delta$ (V1-1), PKC- $\beta$ (V5-3 peptide), and PKC- $\zeta$ (24-26). The specificity of these peptide antagonists has been previously demonstrated in AEC (22). The studies were performed in A549 (ATCC CCL 185) cells stably expressing the rodent $\mathrm{Na}$,K-ATPase $\alpha_{1}$ subunit isoform, which was generated as described previously (27). Experiments were also conducted in A549 cells expressing the rat $\mathrm{Na}, \mathrm{K}$-ATPase $\alpha_{1}$ subunit tagged with GFP as described previously (28).
Cell culture. A549 cells were grown in DMEM supplemented with $10 \%$ FBS, $2 \mathrm{mM}$ L-glutamine, $50 \mu \mathrm{g} / \mathrm{ml}$ gentamicin, $100 \mathrm{U} / \mathrm{ml}$ penicillin, $100 \mu \mathrm{g} / \mathrm{ml}$ streptomycin, and $3 \mu \mathrm{M}$ ouabain to suppress the endogenous $\mathrm{Na}, \mathrm{K}$-ATPase $\alpha_{1}$ subunit. Cells were incubated in a humidified atmosphere of $5 \% \mathrm{CO}_{2} / 95 \%$ air at $37^{\circ} \mathrm{C}$. Construction of the $\mathrm{Na}, \mathrm{K}$-ATPase $\alpha_{1}$ subunit tagged with GFP $\left(G F P \alpha_{1} A 549\right)$ and the establishment of a stable cell line expressing this construct were performed as described (28). To generate $\rho^{0}$-A549 cells, wild-type A549 cells were incubated in medium containing ethidium bromide $(50 \mathrm{ng} / \mathrm{ml})$, sodium pyruvate $(1 \mathrm{mM})$, and uridine $(50 \mu \mathrm{g} / \mathrm{ml})$ for $4-6$ weeks $(29)$. The $\rho^{0}$ status of cells was confirmed by the absence of cytochrome oxidase subunit II by PCR and the failure to grow in the absence of uridine in the medium. Hypoxic conditions $\left(1.5 \% \mathrm{O}_{2}, 93.5 \% \mathrm{~N}_{2}\right.$, and $\left.5 \% \mathrm{CO}_{2}\right)$ were achieved in a humidified variable aerobic workstation $\left(\right.$ INVIVO $\mathrm{O}_{2}$, Ruskinn Technologies, Leeds, UK). The INVIVO $\mathrm{O}_{2}$ contains an oxygen sensor that continuously monitors the chamber oxygen tension.

Preparation of cell lysates and BLMs. After treatment, incubations were terminated by placing the cells on ice and washing them twice with ice-cold PBS. Cell lysates were prepared by addition of lysis buffer $(20 \mathrm{mM}$ Tris- $\mathrm{HCl}$ [pH 7.5], $150 \mathrm{mM} \mathrm{NaCl}, 1 \mathrm{mM}$ EDTA, 1 mM EGTA, $1 \%$ Triton X-100, $2.5 \mathrm{mM}$ sodium pyrophosphate, $1 \mathrm{mM}$ $\beta$-glycerolphosphate, $1 \mathrm{mM} \mathrm{Na}_{3} \mathrm{VO}_{4}, 1 \mu \mathrm{g} / \mathrm{ml}$ leupeptin, $1 \mathrm{mM}$ PMSF) and centrifugation at $14,000 \mathrm{~g}$ to eliminate the insoluble material. BLMs were prepared using Percoll gradient centrifugation as described $(20,22)$. Briefly, cells were scraped in PBS, centrifuged, resuspended in homogenization buffer $(300 \mathrm{mM}$ mannitol in $12 \mathrm{mM}$ Tris-HCl-HEPES [pH 7.6] and protease inhibitors as described above), homogenized, and centrifuged twice to discard the nuclear and mitochondrial pellet. Supernatant was centrifuged at $48,000 \mathrm{~g}$ for 30 minutes, and the BLM fraction was recovered after the membrane pellet was centrifuged in a $16 \%$ Percoll gradient at $48,000 \mathrm{~g}$ for 30 minutes. Equal amounts of proteins from cell lysates or BLMs were resolved by 10\% SDS-PAGE and analyzed by immunoblotting with specific antibodies. Cell surface labeling. Cells were labeled for 1 hour using $0.5 \mathrm{mg} / \mathrm{ml}$ EZ-link NHS-SS-biotin (Pierce Chemical Co., Rockford, Illinois, USA). After labeling, the cells were rinsed three times with PBS containing $50 \mathrm{mM}$ glycine to quench unreacted biotin and then lysed in modified radioimmunoprecipitation buffer (mRIPA; $50 \mathrm{mM}$ Tris- $\mathrm{HCl}$ [pH 8], $150 \mathrm{mM} \mathrm{NaCl}, 1 \% \mathrm{NP}-40$, and $1 \%$ sodium deoxycholate, containing protease inhibitors as described above). Aliquots $(150 \mu \mathrm{g}$ of protein) were incubated overnight at $4^{\circ} \mathrm{C}$ with end-overend shaking in the presence of streptavidin beads (Pierce Chemical Co.). The beads were thoroughly washed (30) and then resuspended in $30 \mu$ of Laemmli sample buffer solution (31). Proteins were analyzed by SDS-PAGE and Western blot.

Determination of Na,K-ATPase activity. Na,K-ATPase activity in intact A549 cells was determined by ouabain- 
sensitive ${ }^{86} \mathrm{Rb}^{+}$(Amersham Biosciences, Arlington Heights, Illinois, USA) uptake as previously described (22). ${ }^{86} \mathrm{Rb}^{+}$influx was quantified by liquid scintillation counter (Beckman Coulter, Fullerton, California, USA). Determination of ROS. Generation of ROS was assessed using 2',7'-dichlorofluorescein diacetate (DCFH-DA; Molecular Probes, Eugene, Oregon, USA) as previously described (18). ROS in cells cause oxidation of DCFH (32), yielding the fluorescent product $2^{\prime}, 7^{\prime}$-dichlorofluorescein (DCF). Cells were incubated with DCFH-DA $(10 \mu \mathrm{M})$ under various experimental conditions. Thereafter, the medium was removed and the cells were lysed by addition of lysis buffer (Promega, Madison, Wiscon$\sin$, USA) and centrifuged at $14,000 \mathrm{~g}$ for 1 minute to remove the cell debris. The supernatant was collected, and fluorescence was measured using a spectrofluorometer (excitation, $500 \mathrm{~nm}$; emission, $530 \mathrm{~nm}$ ). Data were normalized to values obtained from normoxic, untreated controls.

Immunofluorescence. Distribution of $\mathrm{Na}, \mathrm{K}-\mathrm{ATP}$ ase molecules in response to hypoxia was evaluated in GFP $\alpha_{1}$ A549 cells. Cells were fixed in 3.5\% formaldehyde for 9 minutes and mounted using Gelvatol in PBS and 2.5\% DABCO. Cellular distribution of Na,K-ATPase-GFP $\alpha_{1}$ was analyzed by direct fluorescence using a Zeiss LSM 510 laser-scanning confocal microscope (objective Plan Apochromat, $\times 63 / 1.4$ oil) (Zeiss, Heidelberg, Germany). Cross-sections were generated with a $0.2-\mu \mathrm{m}$ motor step. Contrast and brightness settings were adjusted so that all pixels were in the linear range.

Immunoprecipitation and back phosphorylation of the Na,K-ATPase $\alpha_{1}$ subunit. GFP $\alpha_{1}$ A549 cells were incubated under $1.5 \%$ or $21 \% \mathrm{O}_{2}$ for 20 minutes. The incubation was terminated by placing the cells on ice, aspirating the media, and adding immunoprecipitation buffer (20 mM Tris-HCl, 2 mM EGTA, 2 mM EDTA, $30 \mathrm{mM} \mathrm{Na} \mathrm{P}_{2} \mathrm{O}_{7}, 30 \mathrm{mM} \mathrm{NaF}, 1 \mathrm{mM} \mathrm{Na} \mathrm{VO}_{4}, 1 \mathrm{mM}$ PMSF, $10 \mu \mathrm{g} / \mathrm{ml}$ leupeptin [pH 7.4]). The cells were then scraped from the plates, frozen in liquid nitrogen, thawed, sonicated, frozen again, and centrifuged for 2 minutes at $14,000 \mathrm{~g}$. After protein determination, $0.2 \%$ SDS and 1\% Triton X-100 were added to each sample. Equal amounts of protein $(700 \mu \mathrm{g})$ were then incubated with anti-GFP antibody for 2 hours at $4{ }^{\circ} \mathrm{C}$. Protein A/G PLUS-Agarose was added, and the samples were incubated overnight at $4^{\circ} \mathrm{C}$. The samples were then washed twice with immunoprecipitation buffer supplemented with $0.2 \%$ SDS and $1 \%$ Triton X-100 and once with $20 \mathrm{mM}$ Tris- $\mathrm{HCl}$ ( $\mathrm{pH}$ 7.4).

The phosphorylation state of the immunoprecipitated $\mathrm{Na}, \mathrm{K}-\mathrm{ATPase}-\mathrm{GFP} \alpha_{1}$ subunit was assessed in vitro by the "back phosphorylation" method $(23,33)$. The standard reaction mixture for in vitro back phosphorylation of the Na,K-ATPase $\alpha_{1}$ subunit by purified PKC (150 ng per $150 \mu \mathrm{l}, 30$ minutes at $30^{\circ} \mathrm{C}$ ) contained $10 \mathrm{mM}$ $\mathrm{MgCl}_{2}, 0.25 \mathrm{mM}$ EGTA, $0.4 \mathrm{mM} \mathrm{CaCl}_{2}, 0.32 \mathrm{mg} / \mathrm{ml}$ PS, $0.03 \mathrm{mg} / \mathrm{ml}$ DAG, $0.1 \mathrm{mg} / \mathrm{ml} \mathrm{BSA}$, and $20 \mathrm{mM}$ Tris-HCl ( $\mathrm{pH}$ 7.5). The phosphorylation reaction was started by the addition of $\left[\gamma^{32} \mathrm{P}\right]$ ATP (final concentration, $100 \mu \mathrm{M}$;
$1.3 \mu \mathrm{Ci}$ per sample). The reaction was stopped by placing the tubes on ice and washing the beads twice with $20 \mathrm{mM}$ Tris-HCl ( $\mathrm{pH}$ 7.4). Samples were analyzed by SDS-polyacrylamide gel electrophoresis using the Laemmli buffer system (31). Proteins were transferred to nitrocellulose membranes and autoradiographed.

Miscellaneous. Hypoxia-inducible factor- $1 \alpha$ (HIF-1 $\alpha)$ protein was analyzed in nuclear extracts as previously described (18). ATP levels were measured by the luciferin/luciferase method using an ATP Bioluminescence Assay Kit HS II (Boehringer Mannheim, Indianapolis, Indiana, USA). Lactate dehydrogenase release was measured using a commercially available assay (Cytotoxicity Detection Kit, Roche Pharmaceuticals, Indianapolis, Indiana, USA). Protein content was determined according to Bradford (34) using a commercial dye reagent (Bio-Rad Laboratories, Richmond, California, USA) and analyzed by SDS-PAGE and Western blot using a Chemiluminescence Reagent Plus kit (Perkin Elmer Life Sciences Inc., Boston, Massachusetts, USA). Quantitation was performed using densitometric analysis (Eagle Eye II; Stratagene, La Jolla, California, USA).

Statistical analysis. Data are expressed as means \pm SD. Statistical analyses were performed using one-way ANOVA followed by a multiple comparison test (Tukey) when the $F$ statistic indicated significance. Results were considered significant when $P$ was less than 0.05 .

\section{Results}

Response of A549 cells to bypoxia. As depicted in Figure 1a, there were no differences in cell viability or in ATP levels (Figure 1b) in A549 cells exposed to $1.5 \% \mathrm{O}_{2}$ for 60 minutes at $37^{\circ} \mathrm{C}$ as compared with cells incubated at $21 \% \mathrm{O}_{2}$ (normoxia). Hypoxia has been reported to activate several genes involved in metabolism, angiogenesis, and erythropoiesis through the activation of the transcription factor HIF-1 (35). Under normoxic conditions, HIF- $1 \alpha$ protein is rapidly degraded by the ubiquitin-proteasome system. In contrast, hypoxia enhances HIF- $1 \alpha$
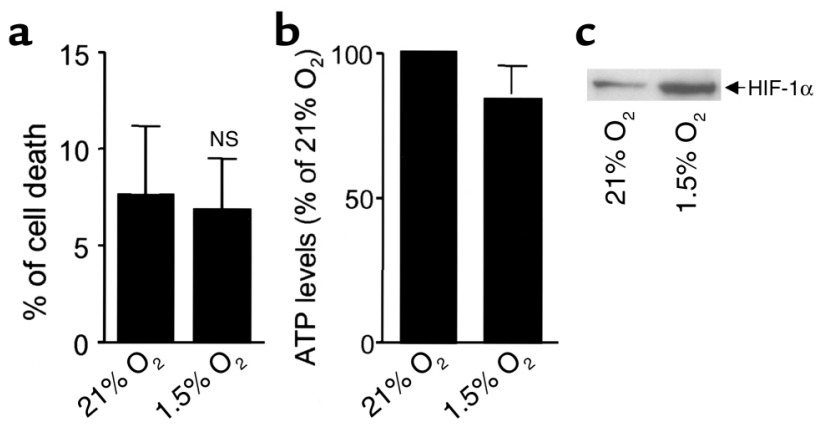

\section{Figure 1}

Effects of hypoxia on cell viability and ATP concentration. Lactate dehydrogenase release (expressed as a percentage of cell death) (a) and ATP levels (expressed as a percentage of $\left.21 \% \mathrm{O}_{2}\right)(\mathbf{b})$ were determined in $\mathrm{A} 549$ cells exposed to $1.5 \% \mathrm{O}_{2}$ for 60 minutes. Bars represent the means \pm SD of three independent experiments. Using the same experimental protocol as above, we determined the HIF- $1 \alpha$ protein levels in nuclear extracts (c); a representative Western blot is shown. 
a

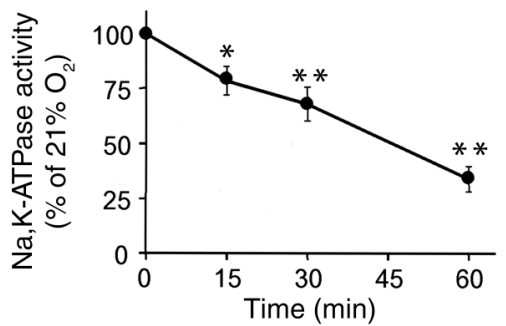

b

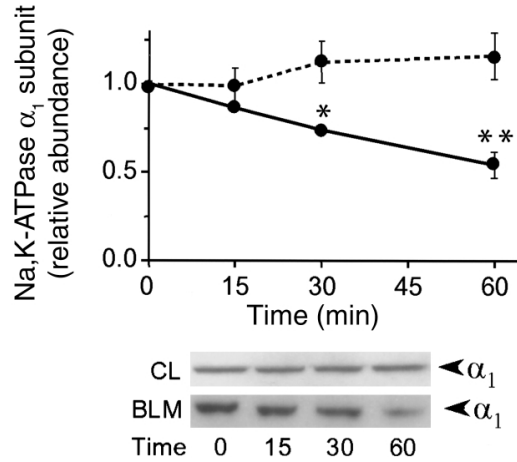

protein levels by inhibiting its degradation (18). As shown in Figure 1c, hypoxia stabilized HIF- $1 \alpha$ protein levels in A549 cells, indicating that it elicits similar molecular responses as other cell types (18).

Effect of hypoxia on alveolar epithelial Na,K-ATPase. Hypoxia induced a time-dependent (as early as 15 minutes) decrease in Na,K-ATPase activity (Figure 2a), which was associated with a decrease in Na,K-ATPase $\alpha_{1}$ subunit protein abundance at the BLM (Figure 2b). The decrease in $\mathrm{Na}$,K-ATPase protein abundance at the plasma membrane was not due to the degradation of the $\mathrm{Na}^{+}$pump, since $\alpha_{1}$ subunit protein abundance in the cell lysate was unchanged (Figure $2 \mathrm{~b}$ ). Milder hypoxia $\left(3 \% \mathrm{O}_{2}\right)$ also induced the endocytosis of the $\mathrm{Na}, \mathrm{K}-$ ATPase $\alpha_{1}$ subunit in A549 cells but only after 120 minutes (data not shown). These results were confirmed by

\section{Figure 2}

Hypoxia decreases $\mathrm{Na}$, K-ATPase activity and $\alpha_{1}$ protein abundance at the plasma membrane. A549 cells were exposed to $1.5 \% \mathrm{O}_{2}$ for 15 , 30 , or 60 minutes. (a) Time-dependent changes in Na,K-ATPase activity were determined by ${ }^{86} \mathrm{Rb}^{+}$uptake and expressed as a percentage of control (control $=21 \% \mathrm{O}_{2}$ ). Data are presented as the means \pm SD of four independent experiments performed in duplicate. ${ }^{*} P<0.05$ and ${ }^{*} P<0.01$. (b) Na,K-ATPase $\alpha_{1}$ subunit abundance in BLM and in cell lysates. Equal amounts of proteins were analyzed (BLM, $5 \mu \mathrm{g}$; cell lysates, $30 \mu \mathrm{g}$ ). Means \pm SD of four experiments (the dotted line represents cell lysates and the solid line represents BLM) and representative Western blots (inset) are shown. ${ }^{*} P<0.05$ and ${ }^{*} P<0.01$. CL, cell lysates.

cell surface biotinylation experiments, which demonstrated that the Na,K-ATPase molecules were endocytosed and not degraded, since the total amount of $\mathrm{Na}$,K-ATPase-labeled molecules did not change when cells were biotinylated before hypoxia (Figure 3, a and b). This effect appears to be specific for the Na,K-ATPase, since the protein abundance of the glucose transporter GLUT1, located at the BLM of epithelial cells (36), was unchanged (Figure 3a, lower panel). These results also suggest that the endocytosed Na,K-ATPase molecules were not degraded during short-term hypoxia. As shown in Figure 3c, reoxygenation of A549 cells with $21 \% \mathrm{O}_{2}$ for 2 hours reversed the effect of hypoxia on $\mathrm{Na}, \mathrm{K}$-ATPase activity and $\alpha_{1}$ subunit protein abundance at the BLM (Figure 3d), suggesting that hypoxia did not cause irreversible damage to $\mathrm{Na}, \mathrm{K}$-ATPase proteins and function. Also, confocal images of subconfluent monolayers of GFP $\alpha_{1}$ A549 revealed that hypoxia induced a redistribution of $\mathrm{Na}$,K-ATPase molecules from BLMs to the cytosol, a process that was reversed by reoxygenation (Figure 3e). GFP $\alpha_{1}$ A549 cells exposed to hypoxia had decreased $\mathrm{Na}, \mathrm{K}-\mathrm{ATP}$ ase activity and $\alpha_{1}$ subunit protein abundance and were not different from wild-type control A549 cells (data not shown).

\section{Figure 3}

Effects of hypoxia on $\mathrm{Na}, \mathrm{K}-\mathrm{ATPa}$ e activity and $\alpha_{1}$ protein abundance at the plasma membrane is specific and reversible. (a) Na,K-ATPase abundance at the plasma membrane was examined in A549 cells exposed to $1.5 \% \mathrm{O}_{2}$ for 60 minutes and surface biotinylated. Cell lysates $(150 \mu \mathrm{g}$ of protein) were pulled down with streptavidin beads. Western blot was performed using Na,K-ATPase $\alpha_{1}$ subunit (upper panel) or GLUT1 (lower panel) antibody. (b) Cells were surface labeled with biotin before hypoxia ( $1.5 \% \mathrm{O}_{2}$ for 60 minutes). Cell lysates ( $150 \mu \mathrm{g}$ of protein) were pulled down with streptavidin beads, and $\mathrm{Na}, \mathrm{K}-\mathrm{ATP}$ ase protein abundance was determined as described in a. (c) A549 cells were exposed to $21 \% \mathrm{O}_{2}$ or $1.5 \% \mathrm{O}_{2}$ for 60 minutes, and then one group $\left(1.5 \% \mathrm{O}_{2}\right)$ was returned to $21 \% \mathrm{O}_{2}$ for 2 hours. Na,K-ATPase activity was determined by ${ }^{86} \mathrm{Rb}^{+}$uptake and expressed as a percentage of control $\left(21 \% \mathrm{O}_{2}\right)$. Bars represent the means \pm SD of three experiments performed in duplicate. ${ }^{*} P<0.01$. (d) A549 cells were exposed to the same protocol as described in c, and Na,K-ATPase abundance was determined. Each bar represents the mean \pm SD of three experiments. A representative Western blot is shown. ${ }^{*} P<0.01$. (e) GFP- $\alpha_{1}$ A549 cells were plated onto glass coverslips and exposed to $21 \% \mathrm{O}_{2}, 1.5 \% \mathrm{O}_{2}$, or $1.5 \% \mathrm{O}_{2}$ and reoxygenation (reox). Cells were fixed and direct fluorescence was visualized using confocal microscopy. Representative confocal images are shown. a
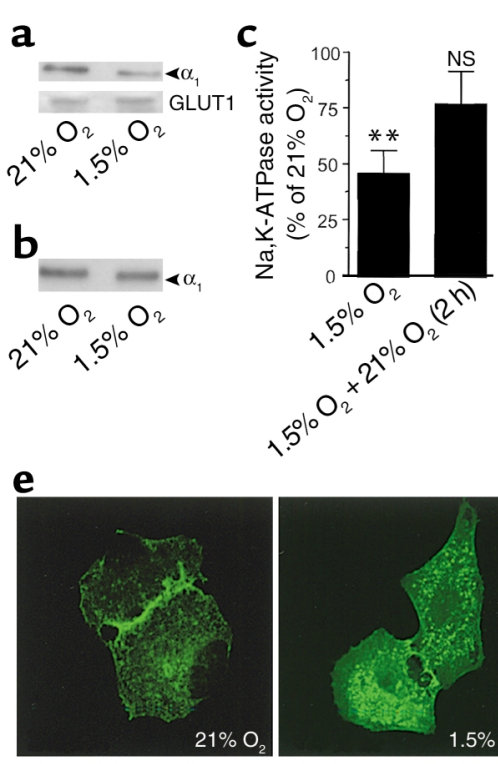
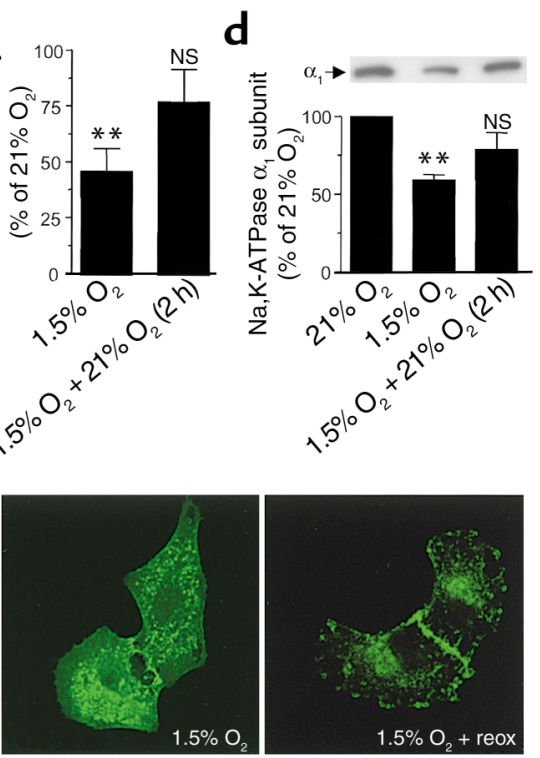
Endocytosis of Na,K-ATPase is mediated by mitochondrial ROS. To determine whether ROS mediate the hypoxiainduced endocytosis of the Na,K-ATPase endocytosis from the plasma membrane, we assessed the production of intracellular ROS in response to $1.5 \% \mathrm{O}_{2}$ using DCFH. DCF fluorescence was increased in cells incubated with DCFH during hypoxia (Figure 4a). No increase in fluorescence was observed when the cells exposed to hypoxia were pretreated with the ROS scavenger NAC or after reexposure to $21 \% \mathrm{O}_{2}$. To determine the source of ROS during hypoxia, A549 cells were pretreated with mitochondrial inhibitors before DCFHloading and exposure to $1.5 \% \mathrm{O}_{2}$. Rotenone plus TTFA (inhibitors of electron transport at complex I and II, respectively) inhibited the increase in DCF fluorescence during hypoxia (Figure 4b). A549 cells treated with antimycin A (AA), a downstream inhibitor of complex III, had increased fluorescence in normoxic conditions, and no further increases were observed during hypoxia (Figure 4b). ROS are initially produced as superoxide, which subsequently is converted to $\mathrm{H}_{2} \mathrm{O}_{2}$ by superoxide dismutase. $\mathrm{H}_{2} \mathrm{O}_{2}$ may be degraded by catalase or by glutathione peroxidase (19). Pretreatment of A549 cells with NAC (a thiol reductive agent), ebselen (a glutathione peroxidase mimetic), or PEG-catalase prevented the hypoxiainduced endocytosis of $\mathrm{Na}, \mathrm{K}$-ATPase molecules (Figure 4c). Further, if ROS act as signal transducers during the hypoxia-induced $\mathrm{Na}, \mathrm{K}$-ATPase endocytosis, then exogenous administration of $\mathrm{H}_{2} \mathrm{O}_{2}$ during normoxia should mimic these effects. Accordingly, $\mathrm{t}-\mathrm{H}_{2} \mathrm{O}_{2}$, a more stable analog of $\mathrm{H}_{2} \mathrm{O}_{2}$, caused a concentration-dependent decrease of $\mathrm{Na}, \mathrm{K}$-ATPase activity (Figure $4 \mathrm{~d}$ ) and endocytosis of molecules from the plasma membrane (Figure 4d, inset).

Experiments were conducted to determine the role of mitochondria-generated ROS during hypoxia-mediated $\mathrm{Na}, \mathrm{K}$-ATPase endocytosis in $\rho^{0}$-A549 cells. $\rho^{0}$-A549 cells are deficient in mitochondrial DNA-derived proteins and are not capable of mitochondrial respiration because they lack key components of the electron transfer chain (16). We generated $\rho^{0}$-A549 cells and through PCR analysis with specific primers confirmed the absence of cytochrome oxidase subunit II DNA in these cells as compared with wild-type A549 cells (Figure 5a). $\rho^{0}$-A549 cells were unable to generate ROS during hypoxia or after incubation with AA in normoxic conditions (Figure $5 \mathrm{~b}$ ). The $\mathrm{Na}, \mathrm{K}$-ATPase activity was unchanged in $\rho^{0}$-A549 cells exposed to $1.5 \% \mathrm{O}_{2}$ for
60 minutes. However, as depicted in Figure 5c, when $\rho^{0}$-A549 cells were treated with $\mathrm{t}-\mathrm{H}_{2} \mathrm{O}_{2}(100 \mu \mathrm{M})$, the $\mathrm{Na}, \mathrm{K}-\mathrm{ATP}$ ase activity and $\alpha_{1}$ subunit protein abundance at the plasma membrane were decreased. These results suggest that $\mathrm{H}_{2} \mathrm{O}_{2}$ must act downstream of the mitochondria and that mitochondria-generated ROS mediate the endocytosis of $\mathrm{Na}, \mathrm{K}$-ATPase molecules.

ROS-dependent endocytosis of Na,K-ATPase molecules requires phosphorylation of the $\alpha_{1}$ subunit. Phosphorylation of the Na,K-ATPase $\alpha_{1}$ subunit at Ser-18 has been reported to trigger $\mathrm{Na}^{+}$pump endocytosis in response to $G$ protein-coupled receptor stimulation in renal cells $(23,37)$. Because ROS are known activators of PKC $(38$, 39), we hypothesized that hypoxia-induced endocytosis of Na,K-ATPase molecules may be mediated by ROSdependent activation of PKC and phosphorylation of the $\mathrm{Na}, \mathrm{K}$-ATPase $\alpha_{1}$ subunit at Ser-18. Preincubation of A549 cells with Bis I, a PKC inhibitor (Figure 6a), prevented the hypoxia-induced decrease in Na,K-ATPase $\alpha_{1}$ subunit abundance at the plasma membrane. Bis I also prevented the $\mathrm{t}-\mathrm{H}_{2} \mathrm{O}_{2}$-induced decrease of Na,K-ATPase
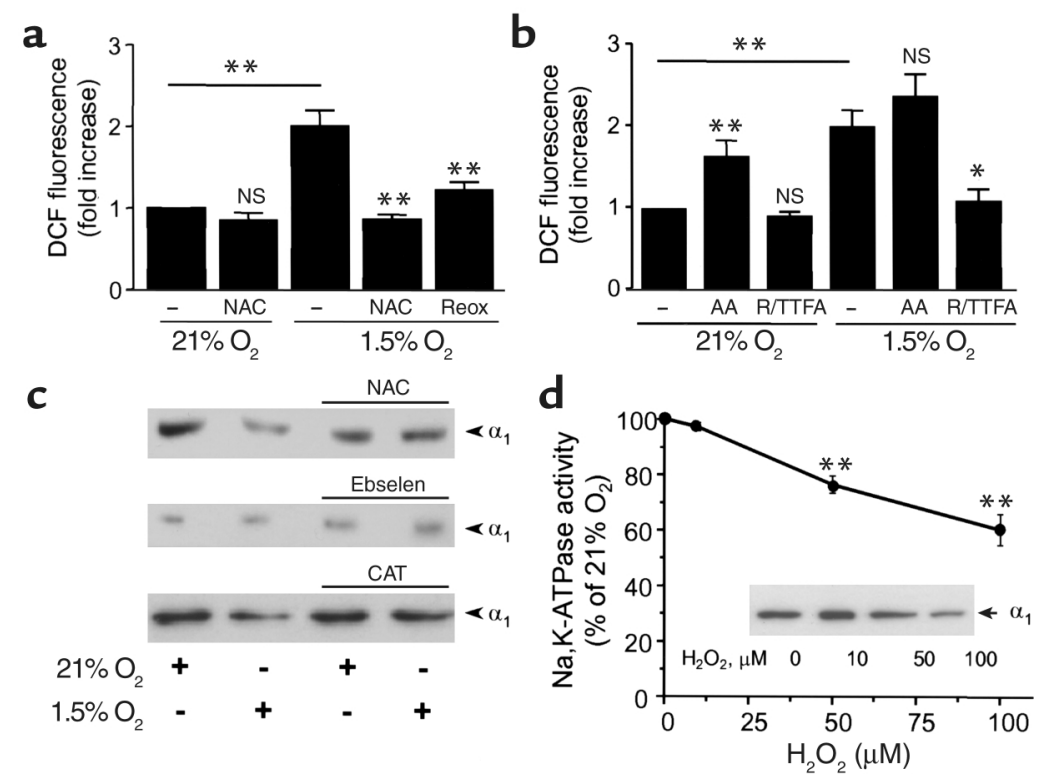

\section{Figure 4}

ROS production in A549 cells during hypoxia. (a) A549 cells were incubated with DCFH-DA $(10 \mu \mathrm{M})$ for 60 minutes under $21 \%$ or $1.5 \% \mathrm{O}_{2}$ in the presence or absence of NAC (10 mM) or reoxygenation (reox) (30 minutes). Fluorescence was measured in cell lysates (excitation, $500 \mathrm{~nm}$; emission, $530 \mathrm{~nm}$ ). Data were normalized to values obtained from normoxic untreated controls. Each bar represents the mean \pm SD of four experiments. ${ }^{*} P<0.01$. (b) A549 cells were preincubated in the presence or absence of AA $(1 \mu \mathrm{g} / \mathrm{ml})$ or rotenone $(1 \mu \mathrm{g} / \mathrm{ml})$ plus TTFA $(10 \mu \mathrm{M})(\mathrm{R} / \mathrm{TTFA})$ and then incubated under $21 \%$ or $1.5 \% \mathrm{O}_{2}$ in the presence of DCFH-DA $(10 \mu \mathrm{M})$ for 60 minutes. Data are presented as the means \pm SD of four experiments. ${ }^{*} P<0.05$ and ${ }^{*} P<0.01$. (c) A549 cells were incubated under $21 \% \mathrm{O}_{2}$ in the presence or absence of NAC (10 $\mathrm{mM}$ ), ebselen $(20 \mu \mathrm{M})$, or PEG-catalase (CAT) and then exposed to $1.5 \% \mathrm{O}_{2}$ for 60 minutes. At the end of the incubation, the cells were surface labeled with biotin. Western blots are representative of three experiments. (d) A549 cells were exposed to $t-\mathrm{H}_{2} \mathrm{O}_{2}$ $(0-100 \mu \mathrm{M})$ for 30 minutes, and $\mathrm{Na}$, K-ATPase activity was determined as ${ }^{86} \mathrm{Rb}^{+}$uptake and expressed as a percentage of control. Each point represents the mean \pm SD of four experiments performed in duplicate. In the inset, A549 cells were exposed to $t-\mathrm{H}_{2} \mathrm{O}_{2}$, and $\mathrm{Na}, \mathrm{K}-\mathrm{ATP}$ ase abundance at BLMs was measured. ${ }^{*} P<0.01$. 


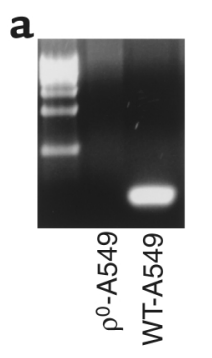

b

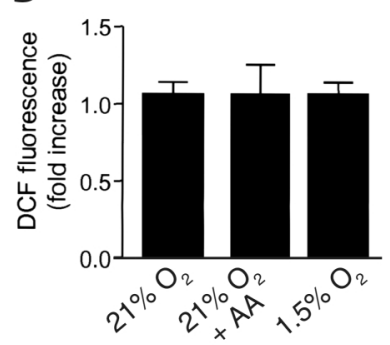

C

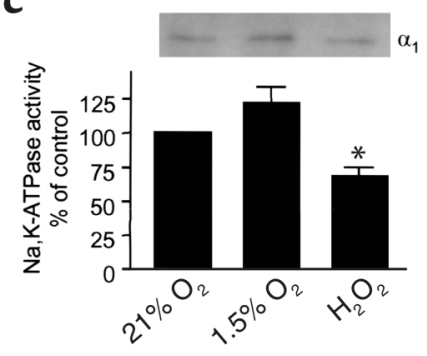

Figure 5

Effect of mitochondrial ROS on Na,K-ATPase activity and abundance in A549 cells. (a) Southern blot analysis of total cellular DNA from wild-type and $\rho^{0}$-A549 cells. Hybridization was performed with a cytochrome oxidase subunit II probe, spanning bp 7757-8195, generated by RT-PCR. (b) $\rho^{0}$-A549 cells were incubated with DCFH-DA $(10 \mu \mathrm{M})$ for 60 minutes at $21 \%$ or $1.5 \% \mathrm{O}_{2}$ in the presence or absence of $A A(1 \mu \mathrm{g} / \mathrm{ml})$. Fluorescence was measured in cell lysates. Data were normalized to values obtained from normoxic untreated controls. Each bar represents the mean \pm SD of three experiments. (c) In the lower panel, $\rho^{0}$-A549 cells were exposed to $21 \% \mathrm{O}_{2}, 1.5 \% \mathrm{O}_{2}$, or $\mathrm{t}-\mathrm{H}_{2} \mathrm{O}_{2}$ $(100 \mu \mathrm{M})$, and $\mathrm{Na}, \mathrm{K}-\mathrm{ATP}$ ase activity was determined by ${ }^{86} \mathrm{Rb}^{+}$uptake and expressed as a percentage of control. Each bar represents the mean \pm SD of three experiments performed in duplicate. ${ }^{*} P<0.05$. In the upper panel, $\rho^{0}$-A549 cells were exposed to $21 \%$ $\mathrm{O}_{2}, 1.5 \% \mathrm{O}_{2}$, or $\mathrm{t}-\mathrm{H}_{2} \mathrm{O}_{2}(100 \mu \mathrm{M})$, and $\mathrm{Na}, \mathrm{K}$-ATPase protein abundance was determined by surface biotinylation as described in Figure 2 .

$\alpha_{1}$ subunit abundance at the plasma membrane. To determine which PKC isozymes mediated the endocytosis of $\mathrm{Na}, \mathrm{K}$-ATPase, we used PKC isozyme-specific peptide antagonists (24-26). A549 cells were pretreated with PKC- $\beta$ (V5-3), PKC- $\delta$ (V1-1), or PKC- $\zeta$ peptide antagonists or a control scramble peptide for $15 \mathrm{~min}$ utes and then exposed to either $21 \%$ or $1.5 \% \mathrm{O}_{2}$ for 60 minutes. As shown in Figure 6b, AEC pretreated with the $\mathrm{PKC}-\zeta$ peptide antagonist prevented the hypoxiainduced endocytosis of the $\mathrm{Na}$,K-ATPase $\alpha_{1}$ subunit. In contrast, neither the classic PKC- $\beta$ peptide antagonist nor the novel PKC- $\delta$ peptide antagonist prevented the hypoxia-induced decrease in $\mathrm{Na}, \mathrm{K}$-ATPase $\alpha_{1}$ subunit abundance at the plasma membrane. Additionally, A549 cells that stably expressed a dominant-negative mutant of PKC- $\zeta(40,41)$ were used to confirm the previous results. In these experiments, hypoxia treatment was also unable to decrease the $\mathrm{Na}, \mathrm{K}$-ATPase protein abundance in plasma membrane (data not shown).

To determine whether the Na,K-ATPase $\alpha_{1}$ subunit was phosphorylated by $\mathrm{PKC}$ in response to hypoxia, we exposed A549 cells to $1.5 \%$ and $21 \% \mathrm{O}_{2}$. The $\mathrm{Na}, \mathrm{K}$ ATPase $\alpha_{1}$ subunit was immunoprecipitated and subjected to an in vitro phosphorylation reaction with purified PKC and $\left[\gamma^{-32} \mathrm{P}\right]$ ATP. Proteins that were phosphorylated in the intact cell should not incorporate ${ }^{32} \mathrm{P}$, because they cannot be furthered phosphorylated in vitro. Conversely, proteins that were not phosphorylated in the intact cell can then be phosphorylated in the in vitro reaction. As shown in Figure 6c, less ${ }^{32} \mathrm{P}$-labeled phosphate was incorporated into the $\mathrm{Na}, \mathrm{K}-\mathrm{ATP} a \mathrm{se} \alpha_{1}$ subunit (identified by immunoblotting) during the in vitro phosphorylation in A549 cells treated with $1.5 \% \mathrm{O}_{2}$ than in cells treated with $21 \% \mathrm{O}_{2}$.
Thus, hypoxia induced the phosphorylation of the $\mathrm{Na}$,K-ATPase $\alpha_{1}$ subunit in A549 cells. Finally, we examined the effect of hypoxia on A549 cells expressing the $\mathrm{Na}$,K-ATPase $\alpha_{1}$ subunit carrying a Ser-to-Ala mutation at position 18 (S18A). Exposure of these cells to hypoxia did not decrease $\mathrm{Na}, \mathrm{K}-\mathrm{ATP}$ ase activity and did not result in endocytosis of $\mathrm{Na}, \mathrm{K}$-ATPase molecules from the plasma membrane (Figure 6d).

\section{Discussion}

This study demonstrates that shortterm severe hypoxia decreases $\mathrm{Na}, \mathrm{K}$ ATPase activity in alveolar epithelial cells through the endocytosis of $\mathrm{Na}, \mathrm{K}$ ATPase molecules from the plasma membrane. The hypoxia-induced endocytosis of the Na,K-ATPase was mediated by mitochondria-generated ROS, the activation of PKC- $\zeta$, and the phosphorylation of $\mathrm{Na}$,K-ATPase $\alpha_{1}$ subunit.

The hypoxia-induced decrease in $\mathrm{Na}$,K-ATPase function was not due to cellular death nor to reduced cellular energy production secondary to oxygen deprivation (Figure 1). In vitro, alveolar epithelial cells exposed to $1.5 \% \mathrm{O}_{2}$ maintained normal ATP levels (Figure 1b). Thus, the hypoxia-induced decrease of the Na,K-ATPase activity and protein abundance was not due to changes in cellular ATP levels. Exposure of alveolar epithelial cells to severe hypoxia has been shown to decrease the steady-state levels of $\alpha_{1}$ and $\beta_{1} \mathrm{Na}, \mathrm{K}-\mathrm{ATPase}$ mRNA (15); however, the short time course of our experiments precludes transcriptional regulation as a major contributor. Additionally, as shown in Figures 2 and 3, hypoxia did not affect the total $\mathrm{Na}, \mathrm{K}$ ATPase protein abundance in cell lysates. The hypoxiainduced decrease in $\mathrm{Na}, \mathrm{K}-\mathrm{ATP}$ ase protein abundance in the BLM could have been mediated by increased fluidphase endocytosis; however, GLUT1 levels at the plasma membrane were not decreased (Figure 3). Collectively, these results provide evidence that during hypoxia, changes in $\mathrm{Na}, \mathrm{K}-\mathrm{ATP}$ ase activity and protein abundance at the plasma membrane are mediated by a defined intracellular signaling mechanism and not as a result of generalized cell damage.

Hypoxia has been shown to increase the generation of mitochondrial ROS at the ubisemiquinone site, where an electron can be transferred to $\mathrm{O}_{2}$ to produce $\mathrm{O}_{2}{ }^{-}$. The production of ROS is directly related to the degree and duration of the hypoxic exposure, and the levels of ROS generated during hypoxia do not appear to be toxic to the cell (32). In the present study, the antioxidants that blocked the hypoxia-induced mitochondrial ROS generation also prevented the endocytosis of Na,K-ATPase (see Figure 4). Thus, we reasoned that mitochondrial ROS were part of the signal transduction pathway elicited by hypoxia. We found 
that A549 cells treated with exogenous $\mathrm{H}_{2} \mathrm{O}_{2}$ (within a micromolar range) caused a dose-dependent decrease in $\mathrm{Na}, \mathrm{K}$-ATPase activity and $\alpha_{1}$ subunit protein abundance at the plasma membrane, mimicking the hypoxic response. The studies were performed at $21 \% \mathrm{O}_{2}$ using a more stable $\mathrm{H}_{2} \mathrm{O}_{2}$ analogue $\left(\mathrm{t}-\mathrm{H}_{2} \mathrm{O}_{2}\right)$ (18), which may be the reason why other investigators did not observe a measurable change in $\mathrm{Na}$,K-ATPase activity with similar concentrations of $\mathrm{H}_{2} \mathrm{O}_{2}$ (42). Inhibition of the electron transport chain with rotenone (site I) plus TTFA (site II) blocked the ROS signal during hypoxia, whereas AA, an inhibitor of complex III, increased ROS production (see Figure 4). Supporting these data are the experiments in which $\rho^{0}$-A549 cells exposed to $1.5 \% \mathrm{O}_{2}$ failed to increase DCFH oxidation and to decrease the Na,K-ATPase activity and its endocytosis. However, $\rho^{0}$-A549 cells incubated with $\mathrm{H}_{2} \mathrm{O}_{2}$ had decreased $\mathrm{Na}$,K-ATPase activity and protein abundance at the plasma membrane, indicating that these cells retain the ability to respond and, importantly, that $\mathrm{H}_{2} \mathrm{O}_{2}$ acts downstream of the mitochondria (see Figure 5).

The signal transduction pathways that couple increases in ROS and cellular functions are incompletely understood. A recent report implicated $\mathrm{H}_{2} \mathrm{O}_{2}$ as an intracellular messenger that modulates protein phosphorylation on serine-threonine or tyrosine residues (43). It has been suggested that low levels of ROS could activate PKC $(38,39)$. Exposure of cells to $\mathrm{H}_{2} \mathrm{O}_{2}$ caused tyrosine phosphorylation of various PKC isoforms $(-\alpha,-\beta \mathrm{I},-\delta,-\gamma,-\varepsilon$, and $-\zeta)$ and resulted in their activation in the absence of receptor-mediated stimulation of phospholipase C (39). Both activation and inhibition of Na,K-ATPase activity appear to be PKC mediated $(22,23,44)$. We have previously reported that the catecholamine-mediated exocytosis of $\mathrm{Na}, \mathrm{K}$ ATPase molecules was dependent on the activation of novel but not classic PKC. In the current study, we provide evidence that $\mathrm{PKC}-\zeta$ plays a pivotal role in hypoxia-induced $\mathrm{Na}, \mathrm{K}-\mathrm{ATP}$ ase endocytosis. As shown in Figure 6 ( $a$ and $b$ ), the hypoxia-induced endocytosis of the $\mathrm{Na}, \mathrm{K}-\mathrm{ATP}$ ase was mediated by PKC- $\zeta$ but not PKC- $\beta$ or PKC- $\delta$. As shown in Figure $6 c$, PKC phosphorylated the $\mathrm{Na}$,K-ATPase $\alpha_{1}$ subunit in hypoxia-treated A549 cells. It has been previously reported that Ser-18 in the $\alpha_{1}$ subunit of the Na,K-ATPase is the major site for PKCmediated phosphorylation of Na,K-ATPase (45). Therefore, we transfected A549 cells with the rodent $\alpha_{1}$ subunit lacking the PKC phosphorylation site. As shown in Figure 6d, in Ser-18-A549 cells exposed to $1.5 \% \mathrm{O}_{2}$, the $\mathrm{Na}, \mathrm{K}$-ATPase activity and $\alpha_{1}$ protein abundance at the plasma membrane and in total cell lysates was unchanged, suggesting that the phosphorylation of Ser-18 (PKC site) is required for the hypoxia-mediated endocytosis of the Na,K-ATPase in alveolar epithelial cells. These effects bear similarity to the mechanisms involved in the clathrin-dependent endocytosis of renal $\mathrm{Na}, \mathrm{K}$-ATPase in response to a $\mathrm{G}$ protein-coupled receptor signal $(23,37)$ and warrant further studies for the elucidation of the differences and similarities between hypoxia and $G$ protein-coupled receptor regulation of $\mathrm{Na}, \mathrm{K}-\mathrm{ATP}$ ase function.

In summary, our data suggest that alveolar epithelial cells exposed to severe hypoxia through mitochondriagenerated ROS activate an intracellular signaling pathway, triggering the endocytosis of $\mathrm{Na}$, K-ATPase mole-
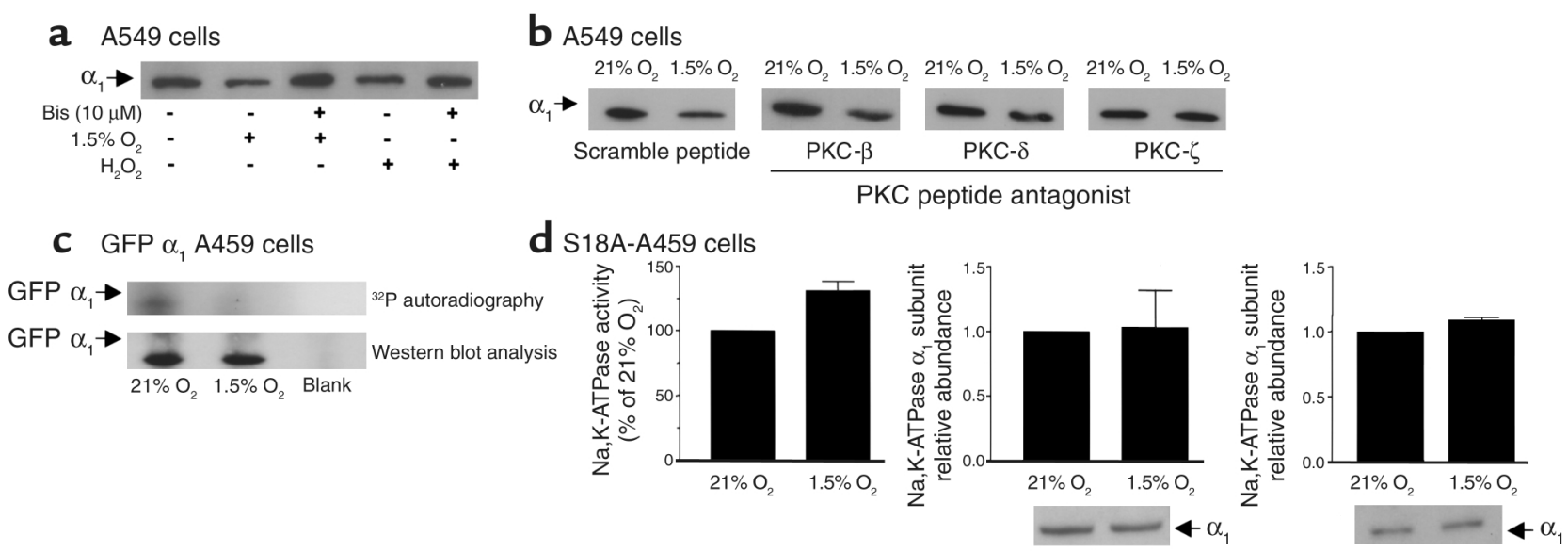

\footnotetext{
Figure 6

Effect of PKC activation and Ser-18 mutation on Na,K-ATPase activity and abundance in A549 cells. (a) Cells were preincubated with 10 $\mu \mathrm{M}$ Bis or vehicle for 30 minutes, exposed to $1.5 \% \mathrm{O}_{2}$ or $\mathrm{H}_{2} \mathrm{O}_{2}(100 \mu \mathrm{M})$, and then surface labeled with biotin. Western blots are representative of three experiments. (b) A549 cells were preincubated with PKC- $\beta$, $-\delta$, or $-\zeta$ peptide antagonists $(0.1 \mu \mathrm{M})$ or with a scramble peptide for 15 minutes and exposed to $1.5 \% \mathrm{O}_{2}$ for 60 minutes. Cells were surface labeled with biotin as described above. A representative autoradiogram is shown $(n=3)$. (c) GFP $\alpha_{1}$ A549 cells were exposed to $1.5 \% \mathrm{O}_{2}$ for 20 minutes, and Na, K-ATPase GFP $\alpha_{1}$ subunit was immunoprecipitated using a polyclonal GFP antibody. An in vitro phosphorylation reaction with the immunoprecipitated Na,K-ATPase, purified PKC, and $\left[\gamma^{-32}\right.$ P]ATP was conducted. A representative autoradiogram of the $\alpha_{1}$ subunit phosphorylation from one of three experiments is shown with the corresponding immunoblot performed with a monoclonal anti-GFP antibody. (d) Na,K-ATPase activity and $\alpha_{1}$ subunit abundance in cell lysates and BLM lysates from S18A-A549 cells submitted to hypoxia for 60 minutes. Each bar represents the mean \pm SD of four different experiments. Corresponding representative Western blots are also shown for each experimental condition.
} 
cules through the activation of PKC- $\zeta$ and phosphorylation of Ser-18 of the $\alpha_{1}$ subunit of $\mathrm{Na}, \mathrm{K}$-ATPase. These cellular events associated with severe hypoxia may contribute to clinical situations such as those occurring during the ascent to high altitudes or during pulmonary edema and hypoperfusion of edematous regions of the lung.

\section{Acknowledgments}

This study was supported in part by NIH grants HL 71218, GM60472-03, and DK53460. K. M. Ridge is a Parker B. Francis Fellow. The authors are grateful to $\mathrm{H}$. Trejo, E. Lecuona, and A. Ciechanover for their help and discussions.

1. Matthay, M.A., Folkesson, H.G., and Verkman, A.S. 1996. Salt and water transport across alveolar and distal airway epithelia in the adult lung. Am. J. Physiol. 270:L487-L503.

2. Factor, P., et al. 1998. Augmentation of lung liquid clearance via adenovirus-mediated transfer of a $\mathrm{Na}, \mathrm{K}-\mathrm{ATP}$ ase $\beta 1$ subunit gene. J. Clin. Invest. 102:1421-1430.

3. Sznajder, J.I. 2001 . Alveolar edema must be cleared for the acute respiratory distress syndrome patient to survive. Am. J. Respir. Crit. Care Med. 163:1293-1294.

4. Rodriguez-Boulan, E., and Nelson, W.J. 1989. Morphogenesis of the polarized epithelial cell phenotype. Science. 245:718-725.

5. Canessa, C.M., et al. 1994. Amiloride-sensitive epithelial $\mathrm{Na}^{+}$channel is made of three homologous subunits. Nature. 367:463-467.

6. Matalon, S., and O-Brodovich, H. 1999. Sodium channels in alveolar epithelial cells: molecular characterization, biophysical properties, and physiological significance. Annu. Rev. Physiol. 61:627-661.

7. Sznajder, J.I., Olivera, W.G., Ridge, K.M., and Rutschman, D.H. 1995. Mechanisms of lung liquid clearance during hyperoxia in isolated rat lungs. Am. J. Respir. Crit. Care Med. 151:1519-1525.

8. Ware, L.B., and Matthay, M.A. 2000. The acute respiratory distress syndrome. N. Engl. J. Med. 342:1334-1349.

9. Skou, J.C., and Esmann, M. 1992. The Na,K-ATPase. J. Bioenerg. Biomembr. 24:249-261.

10. McDonough, A.A., Geering, K., and Farley, R.A. 1990. The sodium pump needs its $\beta$ subunit. FASEB J. 4:1598-1605.

11. Clerici, C., and Matthay, M.A. 2000. Hypoxia regulates gene expression of alveolar epithelial transport proteins. J. Appl. Physiol. 88:1890-1896.

12. Vivona, M., Matthay, M., Chabaud, M., Friedlander, G., and Clerici, C. 2001. Hypoxia reduces alveolar epithelial sodium and fluid transport in rats: reversal by $\beta$-adrenergic agonist treatment. Am. J. Respir. Cell. Mol. Biol. 25:554-561.

13. Planes, C., Friedlander, G., Loiseau, A., Amiel, C., and Clerici, C. 1996. Inhibition of Na-K-ATPase activity after prolonged hypoxia in an alveolar epithelial cell line. Am. J. Physiol. 271:L70-L78.

14. Mairbaurl, H., Wodopia, R., Eckes, S., Schulz, S., and Bartsch, P. 1997. Impairment of cation transport in A549 cells and rat alveolar epithelial cells by hypoxia. Am. J. Physiol. Lung Cell. Mol. Physiol. 273:L797-L806.

15. Wodopia, R., et al. 2000. Hypoxia decreases proteins involved in epithelial electrolyte transport in A549 cells and rat lung. Am. J. Physiol. Lung Cell. Mol. Physiol. 279:L1110-L1119.

16. Chandel, N.S., et al. 1998. Mitochondrial reactive oxygen species trigger hypoxia-induced transcription. Proc. Natl. Acad. Sci. U. S. A. 95:11715-11720

17. Prasad Gabbita, S., Robinson, K.A., Steward, C.A., Floyd, R.A., and Hensley, K. 2000. Redox regulatory mechanism of cellular signal transduction. Arch. Biochem. Biophys. 376:1-13.

18. Chandel, N.S., et al. 2000. Reactive oxygen species generated at mitochondrial complex III stabilize hypoxia-inducible factor- $1 \alpha$ during hypoxia: a mechanism of $\mathrm{O}_{2}$ sensing. J. Biol. Chem. 275:25130-25138.

19. Chandel, N.S., and Schumacker, P.T. 2000. Cellular oxygen sensing by mitochondria: old questions, new insight. J. Appl. Physiol. 88:1880-1889.

20. Bertorello, A.M., Ridge, K.M., Chibalin, A.V., Katz, A.I., and Sznajder, J.I. 1999. Isoproterenol increases $\mathrm{Na}^{+}-\mathrm{K}^{+}$-ATPase activity by membrane insertion of $\alpha$-subunits in lung alveolar cells. Am. J. Physiol. 276:L20-L27.

21. Lecuona, E., Garcia, A., and Sznajder, J.I. 2000. A novel role for protein phosphatase $2 \mathrm{~A}$ in the dopaminergic regulation of $\mathrm{Na}$,K-ATPase. FEBS Lett. 481:217-220

22. Ridge, K.M., et al. 2002. Dopamine-induced exocytosis of Na,K-ATPase is dependent on activation of protein kinase C- $\varepsilon$ and $-\delta$. Mol. Biol. Cell. 13:1381-1389.

23. Chibalin, A.V., et al. 1999. Dopamine-induced endocytosis of $\mathrm{Na}^{+}, \mathrm{K}^{+}-$ ATPase is initiated by phosphorylation of Ser- 18 in the rat $\alpha$ subunit and is responsible for the decreased activity in epithelial cells. J. Biol. Chem. 274:1920-1927.

24. Chen, L., et al. 2001. Opposing cardioprotective actions and parallel hypertrophic effects of $\delta$ PKC and EPKC. Proc. Natl. Acad. Sci. U. S. A 98:11114-11119.

25. Laudanna, C., Mochly-Rosen, D., Liron, T., Constantin, G., and Butcher, E.C. 1998. Evidence of $\zeta$ protein kinase C involvement in polymorphonuclear neutrophil integrin-dependent adhesion and chemotaxis. J. Biol. Chem. 273:30306-30315.

26. Stebbins, E., and Mochly-Rosen, D. 2001. Binding specificity for RACK1 resides in the V5 region of $\beta$ II protein kinase C. J. Biol. Chem. 276:29644-29650.

27. Efendiev, R., et al. 2000. Simultaneous phosphorylation of Ser11 and Ser18 in the $\alpha$-subunit promotes the recruitment of $\mathrm{Na}^{+}, \mathrm{K}^{+}$-ATPase molecules to the plasma membrane. Biochemistry. 39:9884-9892.

28. Cotta-Done, $\mathrm{S}$., et al. 2002. Tyrosine-537 within the $\mathrm{Na}^{+}, \mathrm{K}^{+}$-ATPase $\alpha$-subunit is essential for AP-2 binding and clathrin-dependent endocytosis. J. Biol. Chem. 277:17108-17111.

29. King, M.P., and Attardi, G. 1996. Isolation of human cell lines lacking mitochondrial DNA. Methods Enzymol. 264:304-313.

30. Carranza, M.L., et al. 1998. Protein kinase A induces recruitment of active $\mathrm{Na}^{+}, \mathrm{K}^{+}$-ATPase units to the plasma membrane of rat proximal convoluted tubule cells. J. Physiol. 511:235-243.

31. Laemmli, U.K. 1970. Cleavage of structural proteins during the assembly of the head of bacteriophage T4. Nature. 227:680-685.

32. Duranteau, J., Chandel, N.S., Kulisz, A., Shao, Z., and Schumacker, P.T. 1998. Intracellular signaling by reactive oxygen species during hypoxia in cardiomyocytes. J. Biol. Chem. 273:11619-11624.

33. Walaas, S.I., Browning, M.D., and Greengard, P. 1988. Synapsin Ia, synapsin Ib, protein IIIa, and protein IIIb, four related synaptic vesicleassociated phosphoproteins, share regional and cellular localization in rat brain. J. Neurochem. 51:1214-1220.

34. Bradford, M.M. 1976. A rapid and sensitive method for the quantitation of microgram quantities of protein utilizing the principle of protein-dye binding. Anal. Biochem. 72:248-254.

35. Semenza, G.L. 1999. Regulation of mammalian $\mathrm{O}_{2}$ homeostasis by hypoxia-inducible factor 1. Annu. Rev. Cell Dev. Biol. 15:551-578.

36. Boyer, S., Sharp, P.A., Debnam, E.S., Baldwin, S.A., and Srai, S.K. 1996. Streptozotocin diabetes and the expression of GLUT1 at the brush border and basolateral membranes of intestinal enterocytes. FEBS Lett. 396:218-222.

37. Chibalin, A.V., et al. 1998. Phosphorylation of the catalytic $\alpha$-subunit constitutes a triggering signal for $\mathrm{Na}^{+}, \mathrm{K}^{+}$-ATPase endocytosis. J. Biol. Chem. 273:8814-8819.

38. Yamamoto, T., Matsuzaki, H., Konishi, H., Ono, Y., and Kikkawa, U. 2000. $\mathrm{H}_{2} \mathrm{O}_{2}$-induced tyrosine phosphorylation of protein kinase $\mathrm{c} \delta$ by a mechanism independent of inhibition of protein-tyrosine phosphatase in $\mathrm{CHO}$ and COS-7 cells. Biochem. Biophys. Res. Commun. 273:960-966.

39. Konishi, H., et al. 1997. Activation of protein kinase $\mathrm{C}$ by tyrosine phosphorylation in response to $\mathrm{H}_{2} \mathrm{O}_{2}$. Proc. Natl. Acad. Sci. U. S. A. 94:11233-11237.

40. Berra, E., et al. 1993. Protein kinase C $\zeta$ isoform is critical for mitogenic signal transduction. Cell. 74:555-563.

41. Garcia, A., Cereghini, S., and Sontag, E. 2000. Protein phosphatase 2A and phosphatidylinositol 3-kinase regulate the activity of Sp1-responsive promoters. J. Biol. Chem. 275:9385-9389.

42. Heberlein, W., Wodopia, R., Bartsch, P., and Mairbaurl, H. 2000. Possible role of ROS as mediators of hypoxia-induced ion transport inhibition of alveolar epithelial cells. Am. J. Physiol. Lung Cell. Mol. Physiol. 278:L640-L648.

43. Rhee, S.G., Bae, Y.S., Lee, S.R., and Kwon, J. 2000. Hydrogen peroxide: a key messenger that modulates protein phosphorylation through cysteine oxidation. Sci. STKE. 53:PE1.

44. Efendiev, R., Bertorello, A.M., and Pedemonte, C.H. 1999. PKC- $\beta$ and PKC- $\zeta$ mediate opposing effects on proximal tubule $\mathrm{Na}^{+}, \mathrm{K}^{+}$-ATPase activity. FEBS Lett. 456:45-48.

45. Feschenko, M.S., and Sweadner, K.J. 1997. Phosphorylation of Na,KATPase by protein kinase $\mathrm{C}$ at Ser18 occurs in intact cells but does not result in direct inhibition of ATP hydrolysis. J. Biol. Chem. 272:17726-17733. 